\title{
Implementation of Silvopastoral Systems under Nutrient Cycling in Secondary Vegetation in the Amazon
}

\author{
Perlon Maia dos Santos ${ }^{1}$, Antonio Clementino dos Santos ${ }^{2}$, Durval Nolasco das Neves Neto ${ }^{2}$, \\ Wallace Henrique de Oliveira ${ }^{2}$, Luciano Fernandes Sousa ${ }^{2} \&$ Leonardo Bernardes Taverny de Oliveira ${ }^{2}$ \\ ${ }^{1}$ Universidade Federal Rural da Amazônia, Parauapebas, PA, Brazil \\ ${ }^{2}$ Universidade Federal do Tocantins, Araguaína, TO, Brazil \\ Correspondence: Antonio Clementino dos Santos, Universidade Federal do Tocantins, Campus Araguaína, \\ Araguaína, TO, Brazil. Tel: 55-63-98112-9903. E-mail: clementino@uft.edu.br
}

Received: December 4, $2017 \quad$ Accepted: January 29, $2018 \quad$ Online Published: March 15, 2018

doi:10.5539/jas.v10n4p124 URL: https://doi.org/10.5539/jas.v10n4p124

\begin{abstract}
Silvopastoral systems can be implemented in idle secondary forests; however, they may affect nutrient cycling in these ecosystems. This farming practice using babassu palms (Attalea speciosa Mart.) and Mombasa grass (Panicum maximum Jacq.) has been little studied, and the nutrient cycling occurred during this practice is yet unknown. The goal of this paper was to detect the leaf litter accumulation, decomposition, and nutrient release occurring in silvopastoral systems in a babassu secondary forest, and compared the results with those of a native forest and of a pasture grown under full sunlight. The data relating to deposition, chemical composition, decomposition, and macronutrient release of leaf litter and pasture litter were evaluated by multivariate analyses. The results showed that forest thinning reduced leaf litter deposition and overall nutrient cycling but had no effect on decomposition rates. Conversely, the presence of grass in the understory promoted increased overall nutrient cycling rates. The cycling in integrated systems occurs more similar to that of forests than that of monocultures. The greater the thinning intensity the more similar the cycling will be relative to that occurring in pastures and in monocultures. The nutrients $\mathrm{Ca}, \mathrm{Mg}$, and $\mathrm{N}$ were the most affected by thinning. Moreover, the presence of grass in integrated systems provided an increased $\mathrm{N}$ and $\mathrm{Mg}$ cycling, whereas the thinning reduced Ca cycling. K showed the highest release and return ratio to the soil. Lastly, leaf litter from pasture areas showed higher contents of nutrients, decomposition rates, as well as an enhanced nutrient cycling capacity.
\end{abstract}

Keywords: agroforestry systems, pasture management, leaf litter decomposition

\section{Introduction}

Brazilian livestock farms located in the Cerrado-Amazon ecotone own open areas considered unused and/or in some degree of degradation (Rezende et al., 1999). The alternatives for recovering and reintroducing these areas back to the production system include agroforestry since pasture ecosystems can achieve an increased sustainability level by inserting or maintaining trees to compose silvopastoral systems (SPS). These are alternatives to reincorporate such areas back to the production system (Godinho et al., 2014).

Among the several advantages provided by an SPS (Bahamond et al., 2012; Benavides et al., 2009; Cunha Neto et al., 2013; Wedderburn \& Carter, 1999; Godinho et al., 2014), the nutrient cycling in leaf litter and pasture litter stand out. Some studies have found that if compared to pasture and monoculture, integrated systems promote a greater cycling of base-cation $(\mathrm{Ca}, \mathrm{K}, \mathrm{Mg}$ and $\mathrm{Na}$ ) and other nutrients $(\mathrm{N}$ and $\mathrm{P}$ ) of around 41, 116, 64, 21, 19, and 55\%, respectively (Douglas et al., 2006; Bahamond et al., 2012).

It is known that the adopted model regulates the dynamics of accumulation, decomposition, and nutrient release in an SPS. These processes may occur with greater intensity under an SPS than under pasture monoculture and even native forests when considering forest and understory production. However, the thinning of forests can reduce both deposition and nutrient cycling (Bahamond et al., 2012). In contrast, litter production in pastures could offset the reductions in leaf litter production in forests, and even increase the total nutrient cycling (Guevara-Escobar et al., 2002; Parfitt et al., 1997; Giddens et al., 1997; Gama-Rodrigues et al., 2007; Wedderburn \& Carter, 1999; Godinho et al., 2014). 
In SPSs under random thinning, using babassu as the arboreal component and Mombasa grass as the forage component, the rates of deposition, degradation, and nutrient release from leaf litter are unknown, as well as the effect of the thinning on them. There is also no scientific recommendation for the number of palm trees per hectare, and nutrient cycling is poorly documented in the literature. Given the botanical traits of babassu, the deposition rates might be high, while the decomposition percentages may be low (Benavides et al., 2009; Mancilla-Leyton, Sánchez-Lineros, \& Vicente, 2013) since it has high cellulose and lignin contents, with a high C: $\mathrm{N}$ ratio (Moreira Filho, 2008).

The nutrient cycling in SPS with babassu depends on several factors and may occur mainly in the crowns of trees (Reis et al., 2009; Silva et al., 2009). This can generate specific cycling areas within the system, requiring the use of geoprocessing tools and multivariate analyses, such as cluster and principal component (Minasny \& Mcbratney, 2002; Molin \& Castro, 2008) to measure this cycling and relate these areas to environmental factors.

Given the above, the goals of this paper were to understand the nutrient cycling mechanisms in a silvopastoral system and compare with a native forest and a pasture monoculture. Furthermore, we aimed to identify the contribution of pasture litter for the total nutrient cycling in an SPS. Finally, we sought to highlight which elements are affected by the thinning of forests composing a silvopastoral system.

\section{Material and Methods}

\subsection{Experimental Conditions}

We evaluated areas under a silvopastoral system with babassu and Mombasa grass, under Mombasa grass monoculture, and under native forest. These areas are located in the experimental farm of the Faculty of Veterinary Medicine and Animal Science, Federal University of Tocantins, Campus in Araguaina, Tocantins Brazil. It lies between the geographical longitude of 9213700 and latitude of 9213900 (UTM-NS), and between the meridians 810500 and 810780 (UTM-EW). According to Köppen (1948), the climate is classified as $A w$ (hot and humid), with average annual rainfall of $1800 \mathrm{~mm}$, maximum, minimum, and average temperatures of 40, 18, and $28{ }^{\circ} \mathrm{C}$, respectively. The annual average relative humidity is $76 \%$. The soil is classified as a Plinthic Eutric Red-Argisol.

The total area including SPS and full sun pasture has a deforestation history of over 25 years. Part of this area was soon abandoned, from which a secondary forest developed with a strong presence of babassu palms (Attalea speciosa Mart.); the other part set the stage for a thin shrubbery to take place.

Two silvopastoral systems (SPSs) with native palms (babassu) and Mombasa grass (Panicum maximum Jacq.) were established in the babassu forest area. One of the areas was thinned out until reaching a $60 \%$ shading (SPS 60 ). The other area was thinned out to obtain a $30 \%$ shading (SPS 30).

The shading was adjusted based on illuminance readings (in lux) made with a light meter (LD-200, Instrutherm Ltda, São Paulo, SP, Brazil). These readings were taken at 50 georeferenced points within the SPS, in an equidistant and representative mesh $(8 \times 8 \mathrm{~m})$, which was also used for the sampling of leaf litter deposition and nutrient cycling (Figures 1A and 1B). Both light reading and management in each area were performed according to Silva Neto (2012). 

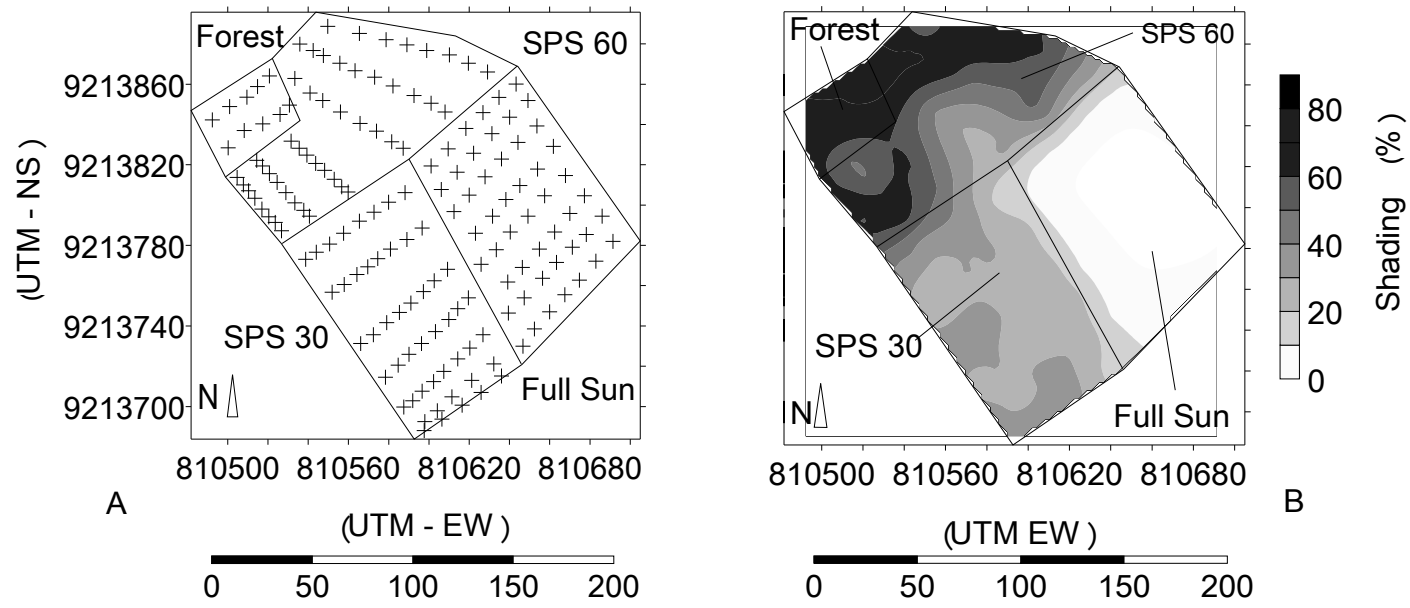

Figure 1. Contour map and layout of the areas and the map collects data (a) and contoured map of shading levels (b) in forest systems, Integration systems SPS 60, SPS30 and full sun

A conventional pasture system was implanted in the thin shrubbery area, i.e. under full sunlight and in monoculture. The surrounding area with native forest was kept unchanged. The dimensions of each area (system or control) were $6,500 \mathrm{~m}^{2}$ (full sun); 7,042.2 $\mathrm{m}^{2}$ (SPS 30); 7,526.2 $\mathrm{m}^{2}$ (SPS 60), and 1,000 $\mathrm{m}^{2}$ (native forest).

\subsection{Correction, Fertilizing and Sowing}

Except for the native forest, the soil in the other areas was fertilized before forage was sown. Sixty days before sowing, $1 \mathrm{Mg} \mathrm{ha}^{-1}$ dolomitic limestone was distributed over the area. Also before sowing, $120 \mathrm{~kg} \mathrm{~K}$ (in $\mathrm{KCl}$ ) and $100 \mathrm{~kg} \mathrm{P}$ (in single superphosphate) were applied to raise the contents of $80-120 \mathrm{mg} \mathrm{dm}^{-3}$ and of $20-30 \mathrm{mg} \mathrm{dm}^{-3}$, respectively. During pasture stabilization stage, $100 \mathrm{~kg} \mathrm{ha}^{-1}$ nitrogen (in urea) was applied, as recommended by Collier et al. (2008). The amounts of lime and fertilizer were distributed manually without incorporation.

Mombasa grass was grown in all the systems. The sowing was held manually in November $2011 \mathrm{with} 7 \mathrm{~kg}$ viable pure seeds per hectare. In March 2012, after pasture was established, the samplings of leaf litter accumulation, forage loss, and decomposition were initiated.

\subsection{Evaluation of Accumulation, Decomposition and Nutrient Release from Leaf Litter}

An adaptation of Wedderburn and Carter's (1999) method, by Silva Neto (2012), was used to quantify the leaf litter production in SPS and native-forest areas, using $0.25-\mathrm{m}^{2}$ surface collectors. These collectors had a wooden frame with a nylon screen $\left(1-\mathrm{mm}^{2} \mathrm{mesh}\right)$ and were installed systematically at 50 georeferenced and equidistant points throughout the areas of SPS and native forest, so the biomass detached from plants could be collected randomly.

To estimate the monthly leaf litter production in the forest, the accumulated material on collectors were taken every 30 days (Mancilla-Leyton et al., 2013). These samples were taken during the months of May, June, September, October, November, and December of 2012, and January and February of 2013. The stored leaf litter was weighed and oven-dried for dry mass determination. With these weights, the biomass returned monthly to the ground could be estimated $\left(\mathrm{g} \mathrm{m}^{-2} \mathrm{month}^{-2}\right)$.

Yet for the litter produced monthly by pasture, the method described by Rezende et al. (1999), and Cecato et al. (2001) was used. Each collector screen had a useful area of $1 \mathrm{~m}^{2}$. Twelve collecting units were installed in each area in the forest. Every month the material deposited on the screen was collected. The litter stored was weighed and oven-dried for dry mass measurements. With these weights, the biomass returned monthly to the ground could be estimated $\left(\mathrm{g} \mathrm{m}^{-2}\right.$ month $\left.^{-2}\right)$.

For leaf litter decomposition, the methods described by Mancilla-Leyton et al. (2013), and Silva Neto (2012) were used, placing 30-g leaf litter into $1-\mathrm{mm}^{2}$ mesh-size litterbags (nylon bags). The decomposition rate was estimated using senescent grass shoot material (above $20 \mathrm{~cm}$ ), according to Bahamond et al. (2012).

The decomposition was measured according to Wedderburn and Carter (1999), wherein the litterbags containing forage returned to the field in the areas under full sun, SPS 30, and SPS 60. Yet, the litterbags with leaf litter were not distributed in full sun area. At each mesh point, 10 nylon bags were distributed on the soil surface, each 
containing the material relating to the respective area. The bags were mixed with the soil leaf litter (Mancilla-Leyton et al., 2013). Every two months one bag of litter and one of forage were taken randomly from each evaluation point, in the integrated areas. Hence, bags with the decomposing material were collected 60, 120, 180, and 240 days after the onset of incubation, as proposed by Bahamond et al. (2012), and Wedderburn and Carter (1999).

Once collected, these bags were transported to the laboratory, where particles smaller than $1 \mathrm{~mm}$, roots, and small invertebrates were removed, and then oven-dried at $55^{\circ} \mathrm{C}$ (Mancilla-Leyton et al., 2013). Corrections for inorganic contaminants (mostly soil particles) were made in agreement with Bahamond et al. (2012).

The residual mass was weighed in an analytical scale with 0.01 -g accuracy, and by comparing it with initial weight $(30 \mathrm{~g})$, the decomposition rate was estimated (g per bimester). The rates of remaining material and decomposition per period (bimester) were calculated according to Cunha Neto et al. (2013) and Silva Neto (2012).

The bimonthly decomposition rate was estimated from the percentage of remaining biomass, both in percent and in grams per period (bimester). And, a first-order exponential equation was used to calculate the daily

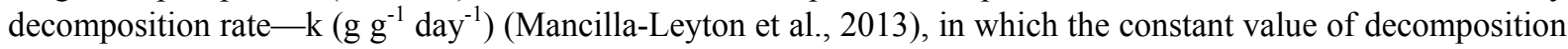
rate for the period was divided by the number of days ( 60 days), as follows:

$$
\mathrm{C}=\mathrm{C}_{0} \mathrm{e}^{-\mathrm{kt} / \text { Period }}
$$

Where, $\mathrm{C}$ is the final sample weight (biomass at the end of 240 days); $\mathrm{C}_{0}$ is the initial weight $(30 \mathrm{~g}) ; \mathrm{t}$ is the incubation time (240 days); $\mathrm{k}$ is the constant of decomposition for the period.

Further, the half-life time of decomposition ( $\mathrm{t}_{1 / 2}$ ) was calculated (Cunha Neto et al., 2013), also according to Rezende et al. (1999), which is the time required to decompose half of the incubated biomass $\left(\mathrm{t}_{0.5} \mathrm{~g} \mathrm{~g}^{-1}\right)$, as follows:

$$
\mathrm{T}_{1 / 2}=\ln (2) / \mathrm{K}
$$

Contents of potassium $(\mathrm{K})$, phosphorus $(\mathrm{P})$, calcium $(\mathrm{Ca})$, magnesium $(\mathrm{Mg})$ and nitrogen $(\mathrm{N})$ were determined for both litter and accumulated/incubated forage (bimester composed-samples, according to Wedderburn and Carter (1999), following the methods in the Embrapa Chemical Analysis Manual (2009). With these concentrations together with the decomposition constants, the accumulation and mineralization rates of these elements over time were then estimated. The absolute amount of each nutrient released in each period (bimester) was calculated according to Bahamond et al. (2012).

\subsection{Statistic}

Data on leaf-litter and litter accumulation; N, P, K, Ca, and Mg accumulations, leaf-litter decomposition, and nutrient release comprised an array of variables codified for systems (4 systems $\times 50$ points) and cycles (7 cycles). There were 19 attributes: leaf litter accumulation; forage loss; $\mathrm{K}$ accumulation; $\mathrm{P}$ accumulation; Ca accumulation; Mg accumulation; $\mathrm{N}$ accumulation; leaf litter degradation; lost forage degradation; $\mathrm{K}$ release by leaf-litter and forage; P release by leaf litter and forage; Ca release by leaf litter and forage; $\mathrm{Mg}$ release by leaf litter and forage; $\mathrm{N}$ release by leaf litter and forage; $\mathrm{K}$ release by leaf litter + forage; $\mathrm{P}$ release by leaf litter + forage; Ca release by leaf litter + forage; $\mathrm{Mg}$ release by leaf litter + forage; $\mathrm{N}$ release by leaf litter + forage, totalizing 1120 assessments.

The data were submitted to descriptive exploratory analysis, and then to multivariate cluster and principal component analyses. These data derived from 50 grid points of each integrated area and from full sun area, besides 10 points from the native forest area, totalizing 160 georeferenced points.

The Ward's Hierarchical Clustering (Vicini, 2005) was used as the algorithm for the clustering of points. The similarity was calculated by Euclidean distance. The separation between groups was determined by Phenon line. Clustering was presented as a dendrogram by grouping similar points.

New variables able to explain the difference among the areas were determined by Principal Component Analysis (PCA). It was made to elucidate which traits most influenced component formation. Therefore, the factors of nutrient cycling most affected by the forest thinning could be enlightened.

Furthermore, the influence of each real variable on the generated components was ascertained. The principal components considered useful are those with eigenvalues above 1 , or that jointly explain more than $70 \%$ of the variation among systems (Mardia et al., 1979). The shading effect, which is related to the level of thinning, was considered a supplement to the PCA, identifying which traits are most affected by this variable. This process identified which cycling traits contribute most to the differentiation of areas. 


\section{Results and Discussions}

\subsection{Leaf Litter Production}

Table 1 shows the results regarding leaf litter production in SPS 30, SPS 60, and forest; litter production in SPS 30 , SPS 60, and full sun; leaf litter and litter decomposition rates; and $\mathrm{K}, \mathrm{P}, \mathrm{Ca}, \mathrm{Mg}$ and $\mathrm{N}$ release by these litter materials over seven cycles.

Leaf litter was produced continuously throughout the evaluation period, with considerable variation between months. The highest leaf litter deposition in integrated areas and forest were recorded in the months of May, June, and September.

Among the systems with arboreal component, the greatest leaf litter production was found for the native forest (average of $62.7 \mathrm{~g}$ leaf litter DM m ${ }^{-2}$ month $^{-1}$ ). The SPS 60 yielded an average of $27.2 \mathrm{~g}$ leaf litter DM m${ }^{-2}$ month $^{-1}$, while SPS 30 produced $27.9 \mathrm{~g}$ leaf litter DM m${ }^{-2}$ month $^{-1}$ (Table 1). These outcomes demonstrate the reduction effect of forest thinning to achieve moderate $(30 \%)$ and high $(60 \%)$ shading levels on the biomass returned to the soil when compared to the forest.

\subsection{Litter Production}

The production of pasture litter originating from forage losses occurred mainly in full sun area, followed by SPS 30. In this case, the SPS 60 had the lowest production (Table 2).

\subsection{Nutrient Accumulation}

The accumulation of $\mathrm{N}, \mathrm{P}, \mathrm{K}, \mathrm{Ca}$, and $\mathrm{Mg}$ from leaf litter in integrated systems was lower than that recorded in the forest. Among the integrated systems (SPS 30 and SPS 60), the greatest accumulations were registered in SPS 30, where leaf litter deposition was higher. $\mathrm{Ca}$ and $\mathrm{Mg}$ were the nutrients with the highest accumulation (returned to the soil) (Table 2). Over time, the greatest accumulation occurred in June (dry season) due to the greater leaf litter production. In general, the exclusive incidence of babassu tended to reduce nutrient cycling.

Nutrient accumulation from pasture litter under the full sun was higher than that from leaf litter, both in integrated systems and in the native forest (Table 1).

\subsection{Leaf Litter and Litter Decomposition}

The overall leaf litter decomposition (biomass \%) was little affected by thinning (Table 1). SPS 30 had numerical superiority relative to SPS 60 and to the forest, which may be related to photobleaching. The decomposition rate of leaf-litter over time, regardless of area, showed a linear decrease from the first to the fourth period (Table 1).

The decomposition rates of pasture litter (SPS 30, SPS 60, and Full Sun), expressed as a percentage of the incubated material, were not modified by the thinning levels, being then similar to each other and equal to litter decomposition in Full Sun.

When considering the entire evaluation period, the leaf litter had the highest decomposition rates (Table 1).

Table 1. Means for cycles (7) of nutrient cycling attributes in Silvopastoral Babassu secondary forest and Mombasa grass systems with 30 and 60\% shading (SPS 30 and SPS 60), native forest and pasture in monoculture in Full sun (FS)

\begin{tabular}{|c|c|c|c|c|c|c|c|}
\hline Cycles & $1 \mathrm{st}$ & 2nd & $3 \mathrm{rd}$ & 4th & 5 th & 6th & 7 th \\
\hline \multicolumn{8}{|l|}{ Monoculture } \\
\hline $\mathrm{LA}\left(\mathrm{g} \mathrm{m}^{-2} \mathrm{month}^{-1}\right)$ & - & - & - & - & - & - & - \\
\hline For. Loss $\left(\mathrm{g} \mathrm{m}^{-2}\right.$ month $\left.^{-1}\right)$ & 22.73 & 25.6 & 17.45 & 74.04 & 83.75 & 67.54 & 61.82 \\
\hline K Ac. $\left(\mathrm{g} \mathrm{m}^{-2} \mathrm{month}^{-1}\right)$ & 0.41 & 0.59 & 0.26 & 1.12 & 1.18 & 0.95 & 0.87 \\
\hline P Ac. $\left(\mathrm{g} \mathrm{m}^{-2}\right.$ month $\left.^{-1}\right)$ & 0.32 & 0.21 & 0.16 & 0.72 & 0.96 & 0.78 & 0.71 \\
\hline Ca Ac. $\left(\mathrm{g} \mathrm{m}^{-2}\right.$ month $\left.^{-1}\right)$ & 0.029 & 0.027 & 0.018 & 0.079 & 0.10 & 0.081 & 0.074 \\
\hline Mg Ac. $\left(\mathrm{g} \mathrm{m}^{-2}\right.$ month $\left.^{-1}\right)$ & 0.021 & 0.020 & 0.014 & 0.063 & 0.083 & 0.067 & 0.061 \\
\hline N Ac. $\left(\mathrm{g} \mathrm{m}^{-2} \mathrm{month}^{-1}\right)$ & 0.48 & 0.45 & 0.32 & 1.38 & 1.78 & 1.43 & 1.31 \\
\hline $\mathrm{LD}(\%)$ & - & - & - & - & - & - & - \\
\hline FD $(\%)$ & 31.54 & & 18.14 & & 16.33 & & 13.80 \\
\hline $\operatorname{KRL}\left(\mathrm{mg} \mathrm{m}^{-2} \mathrm{month}^{-1}\right)$ & 63 & 59 & 24 & 100 & 90 & 73 & 56 \\
\hline $\operatorname{PRL}\left(\mathrm{mg} \mathrm{m}^{-2} \mathrm{month}^{-1}\right)$ & 35 & 33 & 15 & 65 & 74 & 59 & 45 \\
\hline $\operatorname{CaRL}\left(\mathrm{mg} \mathrm{m}^{-2}\right.$ month $\left.^{-1}\right)$ & 4.5 & 4.2 & 1.6 & 7.1 & 7.7 & 6.2 & 4.7 \\
\hline $\operatorname{MgRL}\left(\mathrm{mg} \mathrm{m}^{-2} \mathrm{month}^{-1}\right)$ & 3.2 & 3.0 & 1.3 & 5.7 & 6.4 & 5.1 & 3.9 \\
\hline $\operatorname{NRL}\left(\mathrm{mg} \mathrm{m}^{-2}\right.$ month $\left.^{-1}\right)$ & 73 & 69 & 29 & 120 & 130 & 110 & 84 \\
\hline
\end{tabular}




\begin{tabular}{|c|c|c|c|c|c|c|c|}
\hline \multicolumn{8}{|l|}{ SSP 30} \\
\hline $\mathrm{LA}\left(\mathrm{g} \mathrm{m}^{-2} \mathrm{month}^{-1}\right)$ & 57.04 & 61.91 & 33.27 & 15.40 & 19.07 & 18.79 & 16.56 \\
\hline For. Loss $\left(\mathrm{g} \mathrm{m}^{-2}\right.$ month $\left.^{-1}\right)$ & 11.34 & 13.26 & 11.04 & 32.65 & 50.72 & 41.85 & 48.65 \\
\hline K Ac. $\left(\mathrm{g} \mathrm{m}^{-2} \mathrm{month}^{-1}\right)$ & 0.22 & 0.22 & 0.13 & 0.017 & 0.010 & 0.012 & 0.011 \\
\hline P Ac. $\left(\mathrm{g} \mathrm{m}^{-2} \mathrm{month}^{-1}\right)$ & 0.13 & 1.16 & 0.05 & 0.009 & 0.009 & 0.008 & 0.0086 \\
\hline Ca Ac. $\left(\mathrm{g} \mathrm{m}^{-2}\right.$ month $\left.^{-1}\right)$ & 0.19 & 0.19 & 0.12 & 0.012 & 0.013 & 0.015 & 0.011 \\
\hline Mg Ac. $\left(\mathrm{g} \mathrm{m}^{-2}\right.$ month $\left.^{-1}\right)$ & 0.031 & 0.051 & 0.028 & 0.0023 & 0.013 & 0.0028 & 0.0035 \\
\hline N Ac. $\left(\mathrm{g} \mathrm{m}^{-2}\right.$ month $\left.^{-1}\right)$ & 0.75 & 4.16 & 0.58 & 0.055 & 0.055 & 0.065 & 0.072 \\
\hline LD (\%) & 12.12 & & 9.16 & & 6.76 & & 6.40 \\
\hline $\mathrm{FD}(\%)$ & 33.95 & & 20.21 & & 18.26 & & 14.02 \\
\hline $\operatorname{KRL}\left(\mathrm{mg} \mathrm{m}^{-2}\right.$ month $\left.^{-1}\right)$ & 16 & 81 & 62 & 0.84 & 0.43 & 0.41 & 0.32 \\
\hline $\operatorname{PRL}\left(\mathrm{mg} \mathrm{m}^{-2} \mathrm{month}^{-1}\right)$ & 8.6 & 64 & 2.6 & 0.48 & 0.30 & 0.28 & 0.23 \\
\hline $\operatorname{CaRL}\left(\mathrm{mg} \mathrm{m}^{-2}\right.$ month $\left.^{-1}\right)$ & 12 & 10 & 5.9 & 0.55 & 0.44 & 0.29 & 0.32 \\
\hline $\operatorname{MgRL}\left(\mathrm{mg} \mathrm{m}^{-2}\right.$ month $\left.^{-1}\right)$ & 2.0 & 2.8 & 1.3 & 0.11 & 0.095 & 0.082 & 0.097 \\
\hline $\mathrm{NRL}\left(\mathrm{mg} \mathrm{m}^{-2} \mathrm{month}^{-1}\right)$ & 48 & 44 & 27 & 2.7 & 1.8 & 2.1 & 1.9 \\
\hline \multicolumn{8}{|l|}{$S S P 60$} \\
\hline LA $\left(\mathrm{g} \mathrm{m}^{-2} \mathrm{month}^{-1}\right)$ & 39.14 & 65.30 & 27.30 & 12.12 & 16.35 & 14.78 & 915 \\
\hline For. Loss $\left(\mathrm{g} \mathrm{m}^{-2}\right.$ month $\left.^{-1}\right)$ & 8.15 & 7.92 & 6.14 & 23.94 & 35.30 & 30.71 & 35.64 \\
\hline K Ac. $\left(\mathrm{g} \mathrm{m}^{-2} \mathrm{month}^{-1}\right)$ & 0.016 & 0.050 & 0.023 & 0.011 & 0.014 & 0.013 & 0.005 \\
\hline P Ac. $\left(\mathrm{g} \mathrm{m}^{-2}\right.$ month $\left.^{-1}\right)$ & 0.10 & 0.034 & 0.012 & 0.0066 & 0.008 & 0.0088 & 0.0042 \\
\hline Ca Ac. $\left(\mathrm{g} \mathrm{m}^{-2} \mathrm{month}^{-1}\right)$ & 0.17 & 0.035 & 0.024 & 0.010 & 0.005 & 0.010 & 0.007 \\
\hline $\operatorname{Mg}$ Ac. $\left(\mathrm{g} \mathrm{m}^{-2}\right.$ month $\left.^{-1}\right)$ & 0.011 & 0.007 & 0.006 & 0.0023 & 0.0049 & 0.0024 & 0.0015 \\
\hline N Ac. $\left(\mathrm{g} \mathrm{m}^{-2} \mathrm{month}^{-1}\right)$ & 0.45 & 0.14 & 0.088 & 0.039 & 0.046 & 0.052 & 0.025 \\
\hline $\mathrm{LD}(\%)$ & 11.77 & & 7.73 & & 5.96 & & 5.74 \\
\hline FD $(\%)$ & 32.21 & & 18.73 & & 17.58 & & 14.53 \\
\hline $\operatorname{KRL}\left(\mathrm{mg} \mathrm{m}^{-2}\right.$ month $\left.^{-1}\right)$ & 9.1 & 1.8 & 0.92 & 0.45 & 0.35 & 0.42 & 0.13 \\
\hline $\operatorname{PRL}\left(\mathrm{mg} \mathrm{m}^{-2}\right.$ month $\left.^{-1}\right)$ & 5.5 & 1.2 & 0.48 & 0.27 & 0.24 & 0.27 & 0.10 \\
\hline $\operatorname{CaRL}\left(\mathrm{mg} \mathrm{m}^{-2}\right.$ month $\left.^{-1}\right)$ & 9.3 & 1.9 & 0.95 & 0.43 & 0.15 & 0.31 & 0.17 \\
\hline $\operatorname{MgRL}\left(\mathrm{mg} \mathrm{m}^{-2}\right.$ month $\left.^{-1}\right)$ & 0.58 & 0.41 & 0.24 & 0.099 & 9.3 & 0.088 & 0.039 \\
\hline $\operatorname{NRL}\left(\mathrm{mg} \mathrm{m}^{-2} \mathrm{month}^{-1}\right)$ & 24 & 7.5 & 3.4 & 1.6 & 1.4 & 1.5 & 0.63 \\
\hline \multicolumn{8}{|l|}{ Forest } \\
\hline LA $\left(\mathrm{g} \mathrm{m}^{-2}\right.$ month $\left.^{-1}\right)$ & 89.30 & 126.7 & 98.23 & 35.30 & 35.28 & 25.30 & 29.20 \\
\hline For. Loss $\left(\mathrm{g} \mathrm{m}^{-2} \mathrm{~m}^{-1}\right)$ & - & - & - & - & - & - & - \\
\hline K Ac. $\left(\mathrm{g} \mathrm{m}^{-2} \mathrm{month}^{-1}\right)$ & 0.25 & 0.65 & 0.18 & 3.67 & 0.04 & 0.03 & 0.03 \\
\hline P Ac. $\left(\mathrm{g} \mathrm{m}^{-2}\right.$ month $\left.^{-1}\right)$ & 0.40 & 0.22 & 0.043 & 0.018 & 0.031 & 0.026 & 0.023 \\
\hline Ca Ac. $\left(\mathrm{g} \mathrm{m}^{-2}\right.$ month $\left.^{-1}\right)$ & 0.44 & 0.60 & 0.50 & 0.034 & 0.021 & 0.017 & 0.026 \\
\hline $\operatorname{Mg}$ Ac. $\left(\mathrm{g} \mathrm{m}^{-2}\right.$ month $\left.^{-1}\right)$ & 0.028 & 0.098 & 0.034 & 0.0058 & 0.020 & 0.006 & 0.0066 \\
\hline N Ac. $\left(\mathrm{g} \mathrm{m}^{-2}\right.$ month $\left.^{-1}\right)$ & 0.25 & 1.80 & 0.26 & 0.11 & 0.17 & 0.084 & 0.13 \\
\hline $\operatorname{LD}(\%)$ & 10.82 & & 8.62 & & 6.75 & & 5.33 \\
\hline FD $(\%)$ & - & & - & & - & & - \\
\hline $\operatorname{KRL}\left(\mathrm{mg} \mathrm{m}^{-2}\right.$ month $\left.^{-1}\right)$ & 44 & 35 & 9.2 & 18 & 1.6 & 1.1 & 0.86 \\
\hline $\operatorname{PRL}\left(\mathrm{mg} \mathrm{m}^{-2} \mathrm{month}^{-1}\right)$ & 18 & 24 & 8.7 & 0.93 & 1.1 & 0.97 & 0.63 \\
\hline $\operatorname{CaRL}\left(\mathrm{mg} \mathrm{m}^{-2}\right.$ month $\left.^{-1}\right)$ & 50 & 31 & 9.5 & 1.7 & 0.79 & 0.65 & 0.71 \\
\hline $\operatorname{MgRL}\left(\mathrm{mg} \mathrm{m}^{-2} \mathrm{month}^{-1}\right)$ & 40 & 51 & 11 & 0.29 & 0.31 & 0.22 & 0.17 \\
\hline $\operatorname{NRL}\left(\mathrm{mg} \mathrm{m}^{-2} \mathrm{month}^{-1}\right)$ & 13 & 94 & 13 & 56 & 64 & 31 & 34 \\
\hline
\end{tabular}

Note. Cycle: 28 days: 1st: May; 2nd: June; 3rd: October; 4th: November; 5th: December; 6th: January; 7th: February; LA: leaf litter accumulation; For. Loss: forage accumulation deposited in the soil; $\mathrm{K}$ Ac.: $\mathrm{K}$ accumulation; P Ac.: P accumulation; Ca Ac.: $\mathrm{Ca}$ accumulation; $\mathrm{Mg}$ Ac.: $\mathrm{Mg}$ accumulation; $\mathrm{N}$ Ac.: $\mathrm{N}$ accumulation; LD: leaf litter degradation (bimonthly); FD: forage degradation (bimonthly); KRL: K release by leaf litter; PRL: P release by leaf litter; CaRL: Ca release by leaf litter; MgRL: Mg release by leaf litter; NRL: N release by leaf litter; KRFL: K release by forage and leaf litter; PRFL: P release by forage and leaf litter; CaRFL: Ca release by forage and leaf litter; MgRFL: Mg release by forage and leaf litter; NRFL: N release by forage and leaf litter.

\subsection{Nutrient Release}

Among the systems and throughout the production cycles, there was a similarity between leaf litter and litter nutrient release with the leaf litter and litter deposition since the degradation rates were also similar among them. 
The greatest nutrient release from leaf litter occurred in the forest, followed by SPS 30. Over the cycles, the highest returns of $\mathrm{K}, \mathrm{P}, \mathrm{Ca}, \mathrm{Mg}$, and $\mathrm{N}$ occurred in the months linked to transitional periods (rainfall/dry and dry/rainfall), namely May and September (Table 1).

The release of $\mathrm{K}, \mathrm{P}, \mathrm{Ca}, \mathrm{Mg}$, and $\mathrm{N}$ by pasture litter was higher than the release of these nutrients by leaf litter, either in integrated systems or in the native forest. The release of $\mathrm{K}, \mathrm{P}, \mathrm{Ca}, \mathrm{Mg}$, and $\mathrm{N}$ by leaf litter + pasture litter (total plant cycling) in the integrated systems was greater than were those in the native forest (Table 2).

Table 2. Monthly mean $(7$ cycles) nutrient release by leaf litter + pasture litter in Silvopastoral Babassu secondary forest and Mombasa grass systems with 30 and 60\% shading (SPS 30 and SPS 60), for nutrient release by leaf litter in native forest and by pasture litter in monoculture (Full sun)

\begin{tabular}{llllll}
\hline \multirow{2}{*}{ Site } & \multicolumn{5}{l}{ Nutrient release by leaf litter in native forest and by pasture litter in monoculture $\left(\mathrm{mg} \mathrm{m}^{-2}\right.$ month $\left.^{-1}\right)$} \\
\cline { 2 - 6 } & $\mathrm{K}$ & $\mathrm{P}$ & $\mathrm{Ca}$ & $\mathrm{Mg}$ & $\mathrm{N}$ \\
\hline Monoculture & 67 & 47 & 58 & 47 & 89 \\
SSP 30 & 54 & 38 & 83 & 44 & 12 \\
SSP 60 & 30 & 21 & 40 & 21 & 47 \\
Forest & 40 & 8 & 13 & 27 & 20 \\
\hline
\end{tabular}

\subsection{Decomposition Rate}

If considered the amount of remaining material after incubation and the exposure time thereof, the decomposition rates were fit to an exponential model of biomass loss. The higher the thinning the greater the daily leaf litter decomposition, but it promoted no significant changes in half lifetime (k), in which higher rates of decomposition were found in the forest and lower in SPS 30. The litter degradation constant of pasture was higher than that of leaves for the integrated environments and the forest (Table 3), being the degradation rates similar among all systems.

Table 3. Exponential equations adjusted to litter biomass decomposition values in Silvopastoral systems with 30 and 60\% shading (SPS 30 and SPS 60) and in native forest, and pasture litter decomposition of pasture in monoculture (Full sun) after 8 months of incubation

\begin{tabular}{lllllll}
\hline Site & Equations & $k\left(\mathrm{~g} \mathrm{~g}^{-1}\right.$ day $\left.^{-1}\right)$ & $\mathrm{t}_{0.5}($ Period $)$ & $\mathrm{t}_{0.5}$ (Days) & $\mathrm{t}_{0.5}$ (Months) & $\mathrm{t}_{0.5}$ (Years) \\
\hline Monoculture & $\mathrm{Y}=56.99 \mathrm{e}^{-0.53 \mathrm{P}}$ & 0.0089 & 0.94 & 77.88 & 1.88 & 0.15 \\
SSP 30 & $\mathrm{Y}=31.73 \mathrm{e}^{-0.085 \mathrm{P}}$ & 0.0014 & 5.88 & 495.10 & 11.76 & 0.96 \\
SSP 60 & $\mathrm{Y}=32.08 \mathrm{e}^{-0.088 \mathrm{P}}$ & 0.0015 & 6.68 & 462.09 & 11.36 & 0.93 \\
Forest & $\mathrm{Y}=32.51 \mathrm{e}^{-0.096 \mathrm{P}}$ & 0.0016 & 5.20 & 433.21 & 10.41 & 0.85 \\
\hline
\end{tabular}

Note. P.: period (1, 2, 3 and 4). (k): decomposition constant. $\mathrm{t}_{0.5}$ : time required to decompose half (50\%) of biomass.

\subsection{Multivariate Analysis}

Individual points belonging to each area were grouped by cluster analysis through their mean values ( 7 cycles). The resulting dendrogram (Figure 3) shows, on the vertical axis, a simple Euclidean distance ranging from 0 to 6000 , and on the horizontal axis, the points forming groups.

The averages of points in full sun area (monoculture) were observed to constitute a distinct group. The points belonging to the SPS 30 appeared further to the left of the graph near those of the native forest, while the points of SPS 60 spread mostly within the center. Despite such suggestive grouping, none of these three environments (SPS 60 , SPS 30, and forest) formed distinct groups, as a distance above 3000 (Phenon line - drawn at the highest dissimilarity) is required for a dissimilarity between groups. 

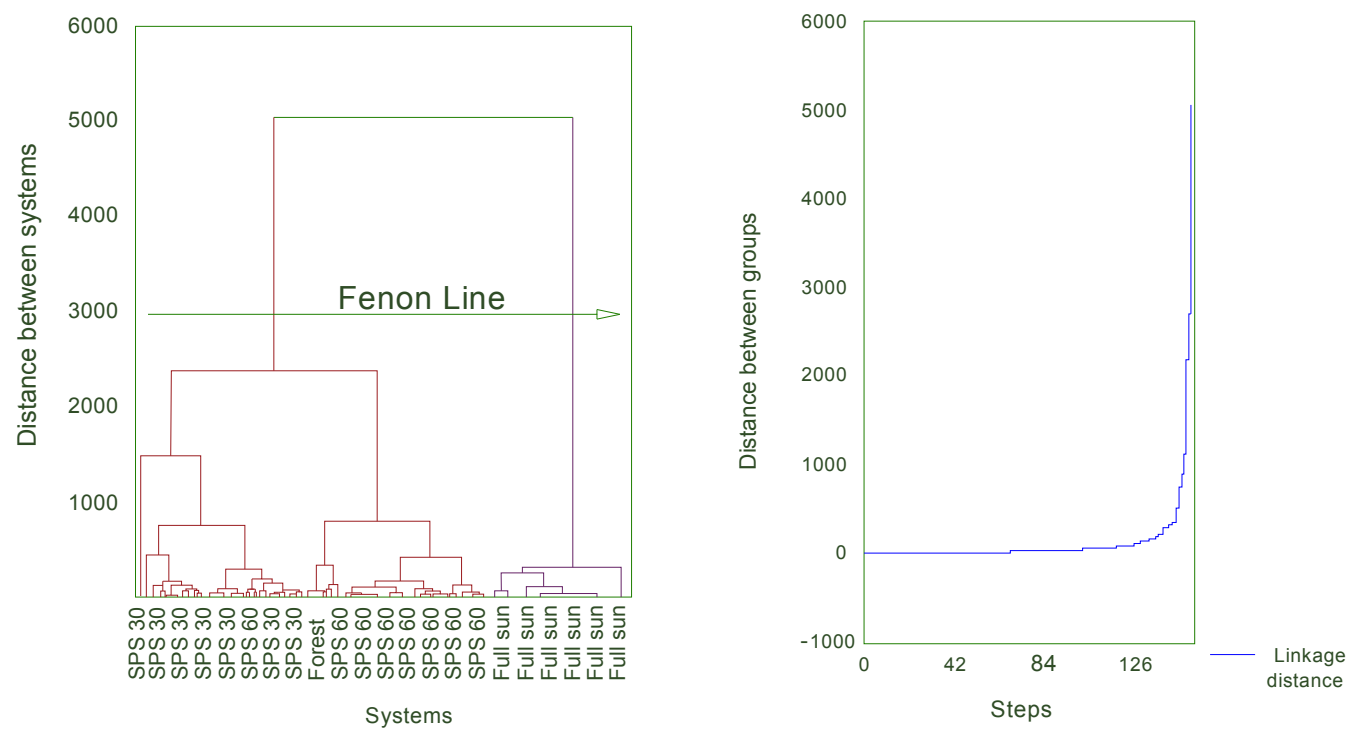

Figure 2. Management systems Dendogram based on nutrient cycling traits and formed by grouping similar mean points of SPS 60, SPS 30 and Full Sun. FS points form a distinct group, while 30 and 60 points form a single group

The similarity between these areas is mainly characterized by the similarity between the average points of SPS 30 and forest and SPS 30 and SPS 60 (Figure 2). FS formed an isolated and distinct group.

The principal component analysis summarized the main features and variations of nutrient cycling that occur among SPS 60, SPS 30, forest and Full Sun. It was also used to list the variables that most were affected by forest thinning (Table 4).

Table 4. Correlation between the original variables and the principal components

\begin{tabular}{llll}
\hline \multirow{2}{*}{ Variables } & \multicolumn{3}{c}{ Components } \\
\cline { 2 - 4 } & $1^{\mathbf{0}}$ & $2^{\mathbf{o}}$ & $3^{\mathbf{o}}$ \\
\hline Ac. Serrap. & $\mathbf{0 . 7 6 0 6 5 0}$ & 0.112473 & -0.231866 \\
Ac. Forrag. & $\mathbf{0 . 7 6 5 4 7 4}$ & 0.315268 & -0.472022 \\
Ac. Nutr. K & $\mathbf{0 . 9 5 6 1 0 8}$ & 0.055235 & 0.186534 \\
Ac. Nutr. P & 0.637917 & 0.663593 & 0.028488 \\
Ac. Nutr. Ca & $\mathbf{0 . 7 6 4 0 6 4}$ & 0.500029 & 0.640739 \\
Ac. Nutr. Mg & $\mathbf{0 . 7 8 1 7 9 6}$ & 0.555483 & 0.166762 \\
Ac. Nutr. N & 0.591042 & 0.645929 & 0.003265 \\
Degrad. Serrap. & $\mathbf{0 . 8 9 0 7 5 9}$ & -0.124388 & -0.192987 \\
Degrad. Forrag. & -0.013110 & -0.300492 & $\mathbf{0 . 8 4 0 1 0 2}$ \\
Lib. Nutri. Serrap. K & $\mathbf{0 . 9 0 2 7 9 1}$ & 0.240800 & 0.125188 \\
Lib. Nutri. Serrap. P & $\mathbf{0 . 8 3 0 3 1 4}$ & 0.473718 & -0.071291 \\
Lib. Nutri. Serrap. Ca & 0.274598 & 0.318005 & 0.677057 \\
Lib. Nutri. Serrap. Mg & $\mathbf{0 . 7 2 6 1 4 6}$ & 0.157415 & 0.092310 \\
Lib. Nutri. Serrap. N & $\mathbf{0 . 8 5 2 9 1 8}$ & 0.252030 & 0.052865 \\
Lib. Nutri. Serrap. + Forrag. K & 0.607082 & 0.502096 & 0.035782 \\
Lib. Nutri. Serrap. + Forrag. P & 0.471322 & $\mathbf{0 . 8 1 6 0 5 4}$ & -0.243838 \\
Lib. Nutri. Serrap. + Forrag. Ca & 0.010087 & $\mathbf{0 . 7 9 6 4 1 0}$ & 0.195236 \\
Lib. Nutri. Serrap. + Forrag. Mg & 0.352737 & $\mathbf{0 . 8 0 8 6 6 3}$ & 0.009707 \\
Lib. Nutri. Serrap. + Forrag. N & -0.033099 & $\mathbf{0 . 9 1 9 5 8 6}$ & -0.006554 \\
\hline
\end{tabular}

Note. Numbers in bold highlight variables with the highest correlation $(>0.70)$ with the formation of principal components; FA: forage accumulation; NutrA.: nutrient accumulation; LLD: leaf litter degradation; PLD: pasture litter degradation; NRLL: nutrient release from leaf litter; NRLLF: nutrient release from leaf litter + forage. 
Three main components were formed with eigenvalue equal to or greater than 1 , in other words, explaining cumulatively over $70 \%$ of the variation in the data of the three systems. These components are formed by the variables closer to the correlation circle and to the axis of the component itself (Figure 3). Therefore, the variability of the areas started to be explained by three components, which represent the original data set, rather than nineteen features, with a loss of explanation of only $21.7 \%$.
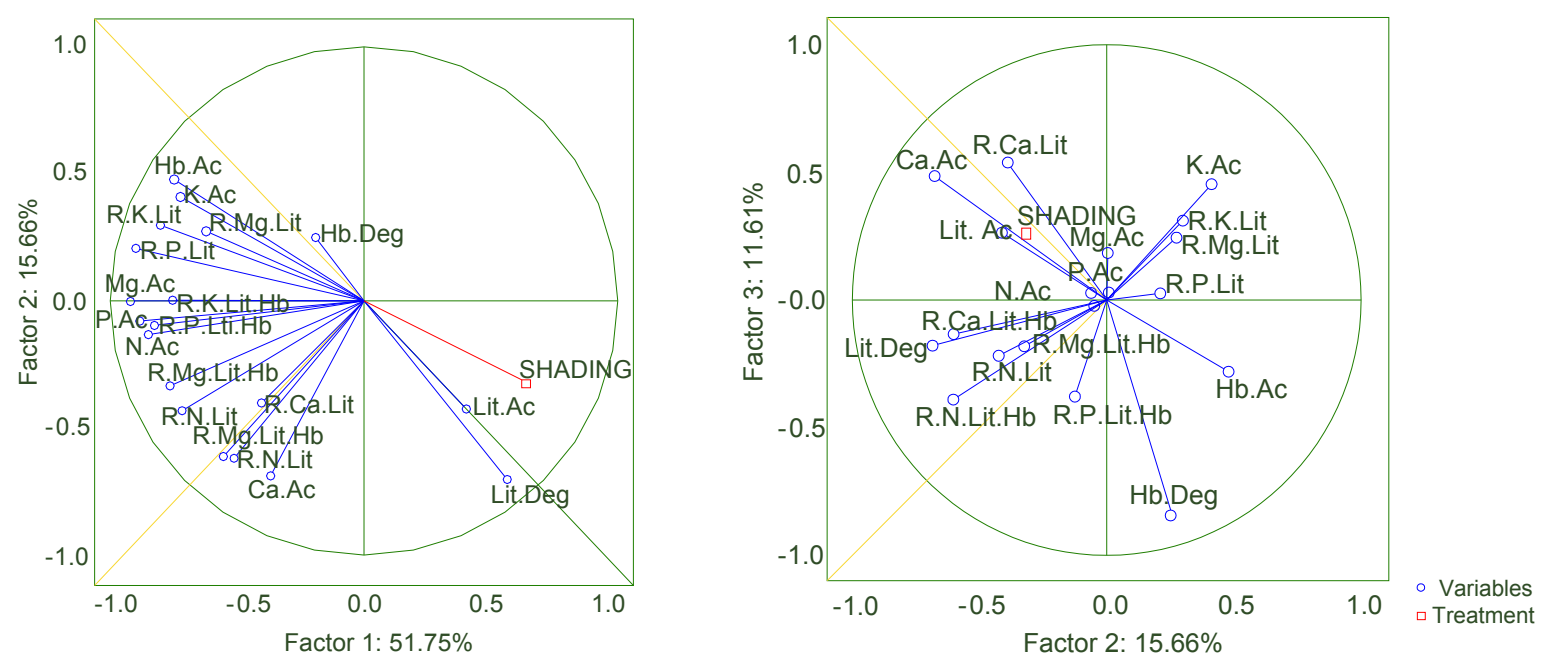

Figure 3. Real variables taken in the composition of the principal components and correlation circle formed between features and principal components depending on the leaf litter deposition in SPS 60, SPS 30 and native forest, forage losses in SPS 60, SPS 30 and Sun full, leaf litter and pasture litter decomposition and $\mathrm{K}, \mathrm{P}, \mathrm{Ca}, \mathrm{Mg}$ and $\mathrm{N}$ release. Traits near the axis of the component and radius near the circle have greater relevance

The first principal component explained $51.5 \%$ of the total data variation. It was composed (correlated) by the following attributes: leaf litter accumulation; forage losses; $\mathrm{K}, \mathrm{Ca}$ and $\mathrm{Mg}$ accumulation; leaf litter degradation; and $\mathrm{K}, \mathrm{P}, \mathrm{Mg}$ and $\mathrm{N}$ release by leaf litter.

The second main component explained only $15.5 \%$ of total data variation. It was composed (correlated) by Ca, $\mathrm{Mg}$ and $\mathrm{N}$ release by leaf litter + pasture litter.

The third main component explained only $11.4 \%$ of total data variation. It was composed (correlated) by pasture litter decomposition. Therefore, the presence of an arboreous component seems to influence the decomposition of litter.

\section{Discussion}

\subsection{Leaf Litter Production}

Despite the removal of trees, leaf litter deposition decreased with the thinning in the SPSs. This was because babassu palms, which produce little leaf litter, were retained. Even though SPS 30 underwent a more intense thinning than SPS 60, no change was observed in biomass deposition, which might have resulted from the presence of semi-deciduous trees in the former (35\% tree species assigned to codominant, intermediate, and suppressed crown classes), while in SPS 60 babassu was the main tree species (90\% dominant species). Benavides et al. (2009) confirmed this assertion when reporting that SPSs with deciduous trees contribute more to biomass deposition and soil nutrient enrichment, as seen in SPS 30.

\subsection{Litter Production}

The highest litter production in full sun occurred due to higher forage density and senescent leaf tissues, which may result from a most intense cellular metabolism, increasing new tissue production and nutrient translocation from older leaves. In addition, this elevated senescence in the open environment might a response to UVB and UVC radiation, which damage the photosynthetic system and causes premature death of plant cells and tissues (Zuk-Golaszewska et al., 2003). To corroborate this, Baligar et al. (2010) asserted that radiation excess is harmful to the photosynthetic apparatus, accelerating leaf senescence. 


\subsection{Nutrient Accumulation}

The higher nutrient return to the soil in the forest compared to the integrated environments is linked with the higher tree density and greater floristic diversity found in the woodlands. Bahamond et al. (2012) reported that the quality of leaf litter is modified by changes in plant diversity proportion, which may have existed in SPSs. K and $\mathrm{N}$ had a lower return to the soil as they are translocated before leaf fall (Bahamond et al., 2012; Diehl et al., 2003).

Both the thinning level and the arboreal components can modify the nutrient amount returned to the soil. The exclusive presence of babassu reduced this return due to low levels of the evaluated elements in its leaf litter, besides the fact that a selective thinning can reduce leaf litter deposition and change its chemical composition (Wedderburn \& Carter, 1999).

The higher accumulation of nutrients in SPS originating from litter is a result of the elevated senescence rates if compared to the integrated environments. Besides of that, another cause is the higher content of these nutrients in the litter when compared to leaf-litter from trees, in which components such as petioles, twigs, bark, among others show high levels of carbonaceous compounds (Wedderburn \& Carter, 1999).

Overall, nutrient return through leaf litter and pasture litter were low, as they show low values of deposition, nutrient concentrations in tissues, and decomposition rate. Therefore, these environments, which are well exploited by livestock, will require an extra supply of nutrients via fertilization for further good yields.

\subsection{Leaf Litter and Litter Decomposition}

The rates of leaf-litter degradation varied among system, which demonstrates that the thinning levels had no sharp effect on decomposition rates; this might have occurred because the decomposing activity of microorganisms was probably not affected (Yang et al., 2012). In brief, the differences in nutrient release found between an integrated system and the forest were mainly resulting from differences in the quantity and quality of the deposited material (Mancilla-Leyton et al., 2013).

In each evaluation period, decomposition rates decreased over time, as nutrient losses from the incubated biomass increased (Brandt et al., 2007). Furthermore, the remaining material generated in each cycle had a high $\mathrm{C}$ : $\mathrm{N}$ ratio, hindering the decomposition activity. This happens because some nutrients are easily extracted from the vegetable matrix, in addition to the fact that various compounds, such as sugars and nitrogen compounds (proteins and peptides), are rapidly degraded, thus remaining only recalcitrant compounds in the biomass such as cellulose, tannins, and lignin (Berg \& Laskowski, 1996).

Mancilla-Leyton et al. (2013) reported that organic matter decomposition varies over time on different magnitudes, tending to reduce with an increase in $\mathrm{C}: \mathrm{N}$ ratio since compounds that are more recalcitrant are produced by the decomposing activity. Therefore, degradation depends partly on the $\mathrm{N}$ content, which promotes increased decomposing efficiency but also accelerates the formation of stable compounds and reduces decomposition rate.

In addition, the litter decomposition reduction over time occurred due to losses of nutrients easily extracted from the vegetable resource and of various nitrogenous molecules rapidly degraded (proteins and peptides), remaining only recalcitrant compounds in the biomass such as lignin, what limited the biological action (Bahamond et al., 2012; Wedderburn \& Carter, 1999). Similarly, Bahamond et al. (2012) reported that the highest decomposition rates occurred within the first 60 days, with a considerable reduction after 180 days.

If compared to leaf litter, litter decomposition is easier to occur due to the higher amount of nitrogen compounds, lower C: $\mathrm{N}$ ratio, higher content of nutrients, and larger spaces between parenchyma (palisade and spongy), which provide a better microbial colonization. In contrast, leaf litter has a large amount of fibrous and lignified tissues (Prescott, 2005).

\subsection{Nutrient Release}

If compared with the forest, the nutrient release by leaf litter in the integrated systems was lower, which is related to quantitative and qualitative reductions in the arboreal component. When comparing SPS 30 and SPS 60 , the latter showed a reduced release of nutrients. Once babassu leaf litter has low nutrient content, this difference might have been conditioned by the greater diversity of plants in SPS 30, albeit with a lower density of trees (Cardenas et al., 2008). Wedderburn and Carter (1998) mentioned that the decomposition of integrated systems is mainly affected by leaf litter quality, followed by environmental conditions. Additionally, the intensive releases at the beginning of the experiment possibly happened due to the higher decomposition rates at the start of incubation and reducing thereafter. 
This increased supply of nutrients through litter varies with the content of these elements in plant tissues, as well as with the litter decomposition rates. This improved nutrient cycling through litter enhances the overall cycling in integrated systems when compared to forest systems. SPS 30 had a higher cycling than SPS 60 because of a higher forage production (Benavides et al., 2009).

\subsection{Decomposition Rate}

Indeed, the higher decomposition rates in a forest could be related to minor climate variations within this environment. Trees and plant cover protect the soil from overheating during the day and from cold winds overnight, keeping the ground level environment stable (Benavides et al., 2009). Also, this increased decomposition in the forest is related to the higher nutrient supply provided; as reported by Mancilla-Leyton et al (2013), nutrient supply accelerates decomposition rates. Further, the selective thinning in favor of babassu palms reduces $\mathrm{N}$ supply to the soil.

Conversely, the decreased decomposition rates in an SPS could result from a reduced soil moisture with an intensive thinning (data not shown) (Yahdjian et al., 2006). The thinning also increases the overall direct radiation on the soil, raising the temperature beyond the optimum for microbial action (Benavides et al., 2009). In short, everything seems to point out that the greater the degree of disturbance by SPS implementation to a natural environment, the higher the degree of changes in nutrient cycling rates.

\subsection{Cluster Analysis}

Although the deposition rates were different, the thinning brought slight changes in SPS 30 and 60 if compared to the forest. However, the arboreal composition promoted the distinction between integrated systems and monoculture in terms of nutrient cycling.

Accordingly, these results confirm the differences in nutrient cycling among environments with trees and under monoculture. The main feature distinguishing an integrated from a monoculture system is leaf littering, observed only in integrated and forest areas; besides that, there is a higher release of $\mathrm{K}$ and $\mathrm{N}$ from leaf litter, being the elements mostly returned to the soil by arboreal components.

Table 2 shows the differences in litter biomass deposition and release of $\mathrm{P}, \mathrm{K}, \mathrm{Mg}$, and $\mathrm{N}$ between integrated and full sunlight areas, being higher under monoculture. Such distinctions in the release of the above-mentioned nutrients originated from pasture litter were mainly observed among SPSs and in full sun areas because of distinctions in biomass deposition, but not necessarily the decomposition of this material.

The first principal components with increased significance and larger weight in the ranking were leaf litter deposition and nutrient return to the soil through leaf litter. According to Silva Neto (2012), the most striking feature in systems with arboreal components and in monocultures is leaf litter deposition. Moreover, $\mathrm{K}, \mathrm{Ca}$, and $\mathrm{Mg}$ are the main elements of leaf litter, and $\mathrm{K}, \mathrm{Mg}$, and $\mathrm{N}$ are the most released in decomposition since they are soluble or compose easily degradable molecules susceptible to leaching and soil washing (Luizão, 2007).

Leaf litter accumulation correlates with shading but not with the nutrient release. In the SPSs, there was a greater biomass deposition owing to the leaf litter and litter masses; however, leaf litter decomposition is slow and so is the nutrient release. In integrated systems, the pasture litter decomposition provides mainly $\mathrm{Ca}, \mathrm{Mg}$, and $\mathrm{N}$, which are added to the amounts released by leaf litter, exceeding the pool of cycled nutrients in the monoculture and even in the forest. However, the higher the shading level, the lower the litter contribution because of a lesser litter production and senescent forage (Benavides et al., 2009).

Overall, the first principal component represents the nutrient cycling through leaf litter. The second shows the contribution of pasture litter to the cycling through the forest. The third reveals the differences of total litter decomposed in integrated environments and in monoculture, highlighting its dependence on the amount of deposited litter. These were the most outstanding attributes found in the studied environments according to the analyzed data, being the most affected by the presence of an arboreal component.

Lastly, the shading effect was considered when using the PCA, where the forest thinning intensity was taken as an additional variable to enable the observation of features mostly influenced by it (Figure 4). The results showed that forest thinning mainly affected the leaf litter deposition.

\section{Conclusions}

The forest thinning reduces leaf litter deposition but has no influence on its decomposition rates, being similar among all integrated systems and in the forest area, decreasing exponentially over time.

In the integrated systems, the grass in the understory increases the overall nutrient-cycling rates, wherein a $30 \%$ shading reaches higher rates. 
The presence of grass in the integrated environments increases $\mathrm{N}, \mathrm{K}$, and $\mathrm{Mg}$ cycling, while the thinning reduces Ca cycling.

\section{References}

Bahamonde, P. L., Héctor, A., Peri, R., Alvarez, A., Barneix, A., Moretto, G., \& Martinez, P. (2012). Litter decomposition and nutrients dynamics in Nothofagus antarctica forests under silvopastoral use in Southern. Agroforest Systems, 84(3), 345-360. https://doi.org/10.1007/s10457-012-9479-7

Baligar, V. C., Gama-Rodrigues, E., Nair, P. K. R., Nair, V. D., Gama-Rodrigues, A. C., \& Machado, R. C. R. (2010). Carbon storage in soil size fractions under two cacao agroforestry systems in Bahia, Brazil. Environmental Management, 45(2), 274-283. https://doi.org/10.1007/s00267-009-9420-7

Benavides, R., Douglas, G., \& Osoro, K. (2009). Silvopastoralism in New Zealand: Review of effects of evergreen and deciduous trees on pasture dynamics. Agroforest Systems, 76(2), 327-350. https://doi.org/ 10.1007/s10457-008-9186-6

Berg, B., \& Laskowski, R. (1997). Changes in nutrient concentrations and nutrient release in decomposing needle litter in monocultural systems of Pinus contorta and Pinus sylvestris: A comparison and synthesis. Scand Journal Forage Research, 12(2), 113-121. https://doi.org/10.1080/02827589709355392

Brandt, L. A., King, J. Y., \& Milchunas, D. G. (2007). Effects of ultraviolet radiation on litter decomposition depend on precipitation and litter chemistry in a shortgrass steppe ecosystem. Global Change Biology, 13(10), 2193-2205. https://doi.org/10.1111/j.1365-2486.2007.01428.x

Cardenas, S. S., \& Ortega, Y. G. (2008). Accumulation and decomposition of litter in pasture of Panicum maximum and in silvopastoral system associated with Leucaena leucocephala. Zootecnia Tropical., 26(3), 269-273.

Cecato, U., Castro, C. R. C., Canto, M. W., Peternelli, M., Almeida Júnior, J. A., Jobim, C. C., \& Cano, C. C. P. (2001). Perdas de forragem em capim tanzânia (Panicum maximum Jacq cv. Tanzania-1) manejado sob diferentes alturas sob pastejo. Revista Brasileira de Zootecnia, 30(2), 295-301. https://doi.org/10.1590/ S1516-35982001000200001

Collier, L. S., Lara, M. A. S., Vilela, L., \& Siqueira, F. L. T. (2008). Recomendação de adubação e calagem a partir do manejo da fertilidade de solos cultivados com pastagens no Cerrado. In A. C. Santos (Ed.), Manejo de solos sob pastagens Tropicais (p.12).

Cunha Neto, F. V., Leles, P. S. S., Pereira, M. G., Bellumath, V. G. H., \& Alonso, J. M. (2013). Acúmulo e decomposição da serapilheira em quatro formações florestais. Ciência Florestal, 23(3), 379-387. https://doi.org/10.5902/1980509810549

Diehl, P., Mazzarino, M. J., Funes, F., Fontenla, S., Gobbi, M., \& Ferrari, J. (2003). Nutrient conservation strategies in native Andean-Patagonian forest. Journal Vegetable Science, 14(1), 63-70. https://doi.org/ 10.1111/j.1654-1103.2003.tb02128.X

Douglas, G. B., Walcroft, A. S., Hurst, S. E., Potter, J. F., Foote, A. G., Fung, L. E., Edwards, W. R. N., \& Van Den Dijssel, C. (2006). Interactions between widely spaced young poplars (Populus spp.) and the understorey environment. Agroforesty System, 67(2), 177-186. https://doi.org/10.1007/s10457-005-3394-0

EMBRAPA (Empresa Brasileira de Pesquisa Agropecuária). (2009). Manual de análises químicas de solos, plantas e fertilizantes (2nd ed.). Brasília: Embrapa comunicação para transferência de tecnologia.

Gama-Rodrigues, A. C., Gama-Rodrigues, E. F., \& Brito, E. C. (2007). Decomposição e liberação de nutrientes de Resíduos culturais de plantas de cobertura em Argissolo vermelho-amarelo na região Noroeste fluminense (RJ). Revista Brasileira de Ciência do Solo, 31(6), 1421-1428. https://doi.org/10.1590/S0100-068320070 00600019

Giddens, M., Parfitt, R. L., \& Percival, H. J. (1997). Comparison of some soil properties under Pinus radiata and improved pasture. New Zealand Journal Agriculture Research, 40(3), 409-416. https://doi.org/10.1080/ 00288233.1997 .9513262

Godinho, T. O., Caldeira, M. V. W., Rocha, J. H. T., Caliman, J. P., \& Trazzi, P. A. (2014). Quantificação de biomassa e nutrientes na serapilheira acumulada em trecho de floresta estacional semidecidual submontana, ES. Revista Cerne, 20(1), 11-20. https://doi.org/10.1590/S0104-77602014000100002 
Guevara-Escobar, A., Kemp, P. D., Mackay, A. D., \& Hodgson, J. (2002). Soil properties of a widely spaced, planted poplar (Populus deltoides)-pasture system in a hill environment. Australian Journal Soil Research, 40, 873-886. https://doi.org/10.1071/SR01080

Köppen, W. (1948). Climatologia: Com um estúdio de los climas de la tierra. Climatology (p. 104). Laboratory of Climatology, New Gersey, EUA.

Luizão, F. J. (2007). Ciclos de nutrientes na Amazônia: Respostas à mudanças ambientais e climáticas. Ciência e Cultura, 59(3), 31-36.

Mancilla-Leytón, J. M., Sánchez-Lineros, V., \& Vicente, A. M. (2013). Influence of grazing on the decomposition of Pinus pinea L. needles in a silvopastoral system in Doñana, Spain. Plant Soil, 373(2), 173-181. https://doi.org/10.1007/s11104-013-01788-8

Mardia, K. V., Kent, J. T., \& Bibby, J. M. (1979). Multivariate analysis (p. 521). London: Academic.

Minasny, B. \& Mcbratney, A. B. (2002). FuzMe, Version 3.0. Australian Center of Precision Agriculture, The University of Sidney.

Molin, J. P., \& Castro, C. N. (2008). Establishing management zones using soil electrical conductivity and other soil properties by the fuzzy clustering technique. Scientia Agricola, 65(6), 5 67-573. https://doi.org/10.1590/ S0103-90162008000600001

Moreira Filho, M. A., \& Oliveira, M. E. (2008). Composição bromatológica de seis espécies nativas do estado do Piauí consumidas por caprinos. PUBVET, 2(34).

Oliveira, F. R. L., Ramos, V. A. M. M. S., Santos, L. D. T., Oliveira, N. J. F., \& Gerasee, V. L. C. (2013). Comportamento de Andropogon gayanus cv. 'planaltina' e Panicum maximum cv. 'Tanzânia' sob sombreamento. Ciência Rural, 43(2), 348-354. https://doi.org/10.1590/S0103-84782013000200026

Parfitt, R. L., Percival, H. J., Dahlgren, R. A., \& Hill, L. F. (1997). Soil and solution chemistry under pasture and radiata pine in New Zealand. Plant Soil, 191(2), 279-290. https://doi.org/10.1023/A:1004266000509

Prescott, C. E. (2010). Litter decomposition: What controls it and how can we alter it to sequester more carbon in forest soils. Biogeochemistry, 101(3), 133-149. https://doi.org/10.1007/s10533-010-9439-0

Reis, G. L., Lana, A. M. Q., Maurício, R. M., Lana, R. M. Q., Machado, R. M., Borges, I., \& Neto, T. Q. (2009). Influence of trees on soil nutriente pools in a silvopastoral system in the Brazilian Savannah. Plant and Soil, 329(2), 185-193.

Rezende, C. P., Cantarutti, R. B., Braga, J. M., Gomide, J. A., Pereira, J. M., Ferreira, E., ... Boddey, R. M. (1999) Litter deposition and disappearance in Brachiaria pastures in the Atlantic forest region of the South of Bahia, Brazil. Nutrient Cycling in Agroecosystems, 54(2), 99-112. https://oi.org/10.1023/A:100979 7419216

Silva Neto, S. P., Santos, A. C., Lima Leite, R. L., Dim, V. P., Neves Neto, D. N., \& Da Cruz, R. S. (2012). Dependência espacial em levantamentos do estoque de carbono em áreas de pastagens de Brachiaria brizantha cv. Marandu. Acta Amazonica, 42(4), 547-556. https://doi.org/10.1590/S0044-59672012000 400013

Silva, C. J., Lobo, F. A., Bleich, M. E., \& Sanches, L. (2009). Contribuição de folhas na formação da serrapilheira e no retorno de nutrientes em floresta de transição no norte de Mato-Grosso. Acta Amazônica, 39(3), 591-600. https://doi.org/10.1590/S0044-59672009000300014

Sousa, L. F., Maurício, R. M., Gonçalves, L. C., Saliba, E. O. S., \& Moreira, G. R. (2007). Produtividade e valor nutritivo da Brachiaria brizantha cv. Marandu em um sistema Silvipastoril. Arquivo Brasileiro de Medicina Veterinária e Zootecnia, 59(4), 1029-1037. https://doi.org/10.1590/S0102-09352007000400032

Vicini, L. (2005). Análise multivariada da teoria á prática. Santa Maria, RS: UFSM, Maria, CCNE.

Wedderbrun, M. E., \& Carter, J. (1999). Litter decomposition by four functional tree types for use in silvopastoral systems. Soil Biology and Biochemistry, 31(3), 455-461. https://doi.org/10.1016/S0038-0717 (98)00151-5

Yahdjian, L., Sala, O. E., \& Austin, A. T. (2006). Differential controls of water input on litter decomposition and nitrogen dynamics in the Patagonian steppe. Ecosystems, 9(1), 128-141. https://doi.org/10.1007/s10021004-0118-7 
Yang, X., Yang, Z., Warren, M. W., \& Chen, J. (2012). Mechanical fragmentation enhances the contribuition of Collembola to leaf litter decomposition. European Journal Soil Biology, 53(2), 23-31. https://doi.org/ 10.1016/j.ejsobi.2012.07.006

Zuk-Golaszewska, K., Upadhyaya, M. K., \& Golaszewski, J. (2003). The effect of UV-B radiation on plant growth and development. Plant Soil Environment, 49(3), 135-140.

\section{Copyrights}

Copyright for this article is retained by the author(s), with first publication rights granted to the journal.

This is an open-access article distributed under the terms and conditions of the Creative Commons Attribution license (http://creativecommons.org/licenses/by/4.0/). 